\section{Plain tobacco packaging in Australia: 26 months on}

\author{
Simon Chapman
}

After a series of false starts, the British government announced that it will bring forward a vote for the plain packaging of tobacco products before the May general election. With extensive support across all three major parties, the Bill is expected to pass easily into law, making Britain the second nation after Australia to take this step. Ten others have indicated their interest in taking the same action, with Ireland, New Zealand, Norway and Turkey being most advanced.

Australia fully implemented its law on plain packaging on 1 December 2012 after it was introduced, unopposed by the Liberal opposition, by the Rudd Labor government, almost a quarter of a century after plain packaging as an approach to tobacco control was first proposed by a Canadian physician Gerry Karr. ${ }^{1}$ Progress from idea to implementation was significantly slowed down by the tobacco industry, concerned about any threat to its profitability. So what were the arguments against such an obvious public health measure, why did it all take so long and what has happened since?

Details of the tobacco industry's dogged campaign, the arguments used for plain packs in Australia and the often absurd and evidence-free claims produced by the 'other side' have recently been set out in an open access book. ${ }^{2}$ The long journey towards Australia's 'plain packaging law' has even included presenting legal arguments to Australia's high court suggesting that the Australian government, by mandating plain packaging, was 'acquiring' the valuable commercial property of the tobacco companies and so there was a case for massive compensation -this was eventually dismissed by $6-1$ in 2012. ${ }^{3}$ Two international challenges to 'plain packaging' remain active, as tobacco companies continue to look for new arguments against any measure designed to reduce tobacco use and so dent their profitability. ${ }^{45}$

The tobacco industry' arguments against plain packaging included contradictory forecasting of its impact: rather like the pushmi-pullyu, the mythical creature from

Correspondence to Dr Simon Chapman, School of Public Health, University of Sydney, A27, NSW 2006, Australia; simon.chapman@sydney.edu.au
Hugh Lofting's Dr Dolittle stories which tried to move in opposite directions at the same time. In 2010, the Alliance of Australian Retailers (the pushmi) ran an industry-funded multimedia campaign insisting that plain packs 'would not work' in that they would not reduce sales of tobacco (see https://www.youtube.com/ watch? $v=$ hjqeiNvBSqw). From the other end, the British American Tobacco (BAT)-funded Institute of Public Affairs (the pullyu), argued the opposite and warned that plain packaging would have an effect greater than any other intervention in the entire history of tobacco control: it would reduce sales by up to $30 \%$ in the first year and by a further $30 \%$ each year after that. ${ }^{6}$

Other contradictory arguments against plain packaging included the prediction that as plain packs would be more easily copied than fully branded packs, they would result in a smugglers' paradise. On the other hand, another argument ran, as branded packs have presented no difficulties to professional counterfeiters in the past it was predicted that smokers, not wanting to be seen dead with the 'uncool' new packs, would queue up at illicit trading outlets to purchase counterfeited branded packs. Ten industrycommissioned reports maintained that around one in seven of all cigarettes being consumed in Australia were sourced from illicit trade. But such figures are not reflected by data from customs authorities. ${ }^{2}$ A BAT spokesman when asked by a British government review team visiting Australia "Have you actually seen a reduction in counterfeit [since the introduction of 'plain packaging']?" replied "Absolutely. Absolutely.",

These arguments were contradictory and missed the point completely. When announcing plain packaging, the then Australian Minister for Health, Nicola Roxon, emphasised "And of course we're targeting people who have not yet started, and that's the key to this plain packaging announcement-to make sure we make it less attractive for people to experiment with tobacco in the first place." 8 Plain packaging, like banning all tobacco advertising, the smoke-free public areas policy and indeed all platforms of tobacco control, is intended to have long-term generational effects and is not expected to work instantly like a rapid action drug. Looking back to Australia's ban on tobacco advertising, there is now a generation-that is all Australians under 23who have never seen a domestic tobacco advertisement. Similarly, the main purpose of plain packaging is to ensure that all future generations of children grow up seeing tobacco products, uniquely among all other consumer goods, packaged without any of the usual glamour of branding but with unforgettable, and utterly unglamorous, health messages. The point is that exceptionally dangerous products must be subject to exceptional packaging legislation. Despite the lessons from past interventions, the tobacco industry called for a single test of effectiveness: an immediate impact on consumption and smoking prevalence among both adults and children. Some in the anti-plain-packaging lobby even asked for evidence of a "sharp decline in smoking prevalence, particularly underage smoking prevalence". 9

A tough journey to get these changes passed into law, but what has been the impact so far? In July 2014, data from the latest triennial national survey of tobacco use in those aged 14 and over were released. ${ }^{10}$ Australia now has the lowest smoking prevalence in this group in the whole world with daily consumption of tobacco by only $12.8 \%$ and less than daily by $3 \%$. Moreover, the percentage fall in daily prevalence between 2010 and 2013 was a record $15.2 \%$. The average percentage decline across the nine surveys since 1991 was $7.6 \%$, with the previous greatest fall being $11 \% .^{11}$ In the same period the percentage of daily smokers aged $12-$ 17 years rose from $2.5 \%$ to $3.4 \%$. This could be seen as 'fodder' to those demanding clear evidence of a 'sharp decline' in smoking prevalence as a response to the new legislation. But in five of 10 data cells that made up the figures, the $\mathrm{SE}$ was $>50 \%$ ('too unreliable for general use') and another two cells with lower SEs "should be used with caution". The main aim of this legislation, working synergistically with previous tobacco control measures, is to affect long-term smoking habits. This is not about quick fixes.

Australia, like Britain, has long taken a comprehensive policy and campaigning approach to tobacco control. This creates significant problems for reductionists keen to specify the exact effect of one element in the synergistic mix of tobacco controls. The Australian government sensibly specified that the objectives of plain packaging 
were discouraging uptake, encouraging cessation and making health warnings more salient. The main group evaluating these issues has published a steady stream of research on impacts ${ }^{12}$ and illicit trade claims. $^{13}$

None of the predicted store chaos, ${ }^{14}$ crime waves or massive price dives occurred in Australia after the introduction of plain packaging and levels of support for the plain packs have risen considerably among smokers, ${ }^{15}$ as has their distaste for the packs. ${ }^{16}$ In 2001, Canada was the first nation to introduce graphic health warnings on cigarette packs. By October 2012, this had increased to 63 nations. The world looks set to see the dominoes again tumble with plain packaging. Britain will be at the front of this hugely important development.

Twitter Follow Simon Chapman at @simonchapman6 Competing interests None.

Provenance and peer review Commissioned; internally peer reviewed.

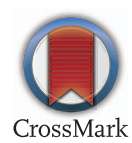

To cite Chapman S. Postgrad Med J 2015;91:119120.

Received 11 February 2015

Accepted 16 February 2015

Postgrad Med J 2015;91:119-120.

doi:10.1136/postgradmedj-2015-133311

\section{REFERENCES}

1 Tully R. Plain Packs History. 1994. http://legacy. library.ucsf.edu/tid/jxd28a99

2 Chapman S, Freeman B. Removing the emperor's clothes. Australia and tobacco plain packaging. Sydney: Sydney University Press, 2014. http://ses. library.usyd.edu.au//bitstream/2123/12257/7/ 9781743324295_Chapman_ RemovingtheEmperorsClothes_FT.pdf

3 High Court of Australia. JT International SA v Commonwealth of Australia [2012] HCA 43. 5 Oct 2012. http://www.austlii.edu.au/au/cases/cth/HCA/ 2012/43.html

4 Voon T, Mitchell AD, Liberman J, Ayres G. eds. Public health and the plain packaging of cigarettes. Legal issues. Cheltenham, UK: Edward Elgar, 2012.

5 Davison M. Big Tobacco vs Australia: Philip Morris scores an own goal. The Conversation. 19 Jan 2012. http://theconversation.com/big-tobacco-vs-australiaphilip-morris-scores-an-own-goal-4967

6 Wilson T. Plain packaging may require up to $\$ 3.4$ billion taxpayer gift annually to big tobacco and film companies. IPA, 26 Apr 2010. http://ipa.org.au/ library/publication/1272344059_document_ governing_in_ignorance_-_26042010.pdf

7 Chantler C. Standardised packaging of tobacco. Report of the independent review undertaken by Sir Cyril Chantler. Apr 2014. http://www.kcl.ac.uk/health/ 10035-TSO-2901853-Chantler-Review-ACCESSIBLE. PDF

Editor's choice

Scan to access mo

8 Australian Government Department of Prime Minister and Cabinet. Transcript of joint doorstop
Commonwealth Parliamentary Offices Sydney. 29 Apr 2010. http://pmtranscripts.dpmc.gov.au/browse.php? $\mathrm{did}=17256$

9 Snowdon C. That plain packaging study. Velvet glove, iron fist [blog], 23 Jul 2013. http:// velvetgloveironfist.blogspot.com.au/2013/07/ that-plain-packaging-study.html

10 Australian Institute of Health and Welfare. National Drugs Strategy Household Surveys (NDSHS). Highlights from the 2013 survey. Canberra: AlHW, 2014; http://www.aihw.gov.au/ alcohol-and-other-drugs/ndshs/

11 Daube M, Chapman S. The Australian's dissembling campaign on tobacco plain packaging. Med JAust 2014:201:191-2.

12 Cancer Council Victoria. Effects of legislation in Australia. Melbourne: Cancer Council Victoria, 2015. https://http://www.cancervic.org.au/plainfacts/browse. asp?Containerl $D=$ effectsoflegislation

13 Cancer Council Victoria. Industry opposition: predicted effects on illicit tobacco. Melbourne: Canvcer Council Victoria, 2015. https://http://www. cancervic.org.au/plainfacts/browse.asp? Container ID=illicittobacco

14 Wakefield M, Bayly M, Scollo M. Product retrieval time in small tobacco retail outlets before and after the Australian plain packaging policy: real-world study. Tobacco Control 2014;23:70-6.

15 Swift E, Borland R, Cummings KM, et al. Australian smokers' support for plain or standardised packs before and after implementation: findings from the ITC Four Country Survey. Tob Control. Published Online First: 10 Nov 2014. doi:10.1136/tobaccocontrol-2014-051880

16 Dunlop SM, Dobbins T, Young JM, et al. Impact of Australia's introduction of tobacco plain packs on adult smokers' pack-related perceptions and responses: results from a continuous tracking survey. BMJ Open 2014;4:e005836. 